\title{
Agonistic possibilities for global unlearning: Constraints to learning within global citizenship education and social movements
}

\author{
Helen Underhill* - Manchester Metropolitan University, UK
}

\begin{abstract}
The continued rise of populisms and divisions alongside widening inequalities nationally and globally give increasing urgency to the question of how educators and activists can respond. This article examines the possibilities that emerge from the connections between global citizenship education (GCE) and learning in social movements, both spaces where people seek to engage others in ideas of how the world is, could and should be. Drawing on Mouffe's (2005) theory of agonistic pluralism to engage conflict and emotion with possibilities for learning and unlearning, the case study reveals the significance of recognizing constraints created by histories and narrations of the 'other'. The article calls for more work on the intersections of unlearning and agonism in order to create agonistic pedagogies for activism and GCE.
\end{abstract}

Keywords: global learning, unlearning, agonism, activism, social movement

\section{Introduction}

The increasingly complex and divided global political landscape within the contemporary moment presents significant challenges for academics, practitioners, educators and activists who seek to develop mutual understandings and responsible behaviours in an increasingly unequal globalized world (Troll and Krause, 2016). Divisive social and economic inequalities at the local, national and global levels (Pogge, 2010) have contributed to rising populism (Mouffe, 2005), to othering (Hall, 1997; Spivak, 2004) and to contestation around understandings of democracy (Underhill, 2016a) and development (Troll and Krause, 2016). As polarizations deepen, the challenge for practitioners and educators who seek to enable 'ethical, responsible and responsive ways of seeing, knowing and relating to others "in context"' (Andreotti, 2010: 239) is more urgent. The reductive nature of public discourse and debate illustrates that, amid the hegemony of liberal structures and institutions that have colonized epistemologies and ontologies (Pashby, 2015), education needs to change to equip learners to negotiate difference (Andreotti, 2009) and create new imaginations and possibilities in an increasingly globalized world.

This article explores possibilities that emerge from learning with difference, drawing new theoretical connections between global citizenship education (GCE) and learning in social movements to highlight the necessity of agonism to both and to develop a framework for activist and citizenship unlearning. The article builds on recent debates of agonism within citizenship education (see Ruitenberg, 2009; Tryggvason, 2017; Zembylas, 2018) to establish unlearning as a critical dimension of a globally 
orientated agonistic pedagogy. First, the article establishes important connections between GCE and learning in social movements. Next, emotion and challenge are brought into conversation with agonism (Mouffe, 2005) to examine conflict within processes of learning and unlearning. The article then presents the methodology and an introduction to the empirical research conducted with diasporic Egyptian activists who engaged in movements with differing narrations of Egypt's revolutionary struggle between 2011 and 2015. Reference to Egypt's continuing struggle in the presentation of the qualitative data intentionally highlights that participants reflected on events beyond the Egyptian Revolution of 25 January 2011 and resistance, and the struggle related to Egypt's revolution continues.

\section{The global in citizenship education and social movement learning}

It is important to acknowledge the contention around terms such as citizenship, development and globalization (see Heater, 2004; Zembylas and Vrasidas, 2005; Young, 2010; Biccum, 2018), which arguably contributes to the lack of unifying definition of subjects such as (global) citizenship education, global learning and development education. Definitions most commonly refer to global awareness, understanding, connection and alongside changing practices (Schattle, 2008; Stein, 2015; Troll and Krause, 2016). It is also widely recognized that these subjects provide spaces for young people to engage in practices of dialogue and explore complex ideas about the world in ways that enable people to act responsibly (Davies, 2006; Andreotti, 2010; Bickmore and Parker, 2014; Bourn, 2014; Troll and Krause, 2016). Practices of engaging with 'how the world is, how the world ought to be and how we can change the conditions of the world' (VanWynsberghe and Herman, 2015: 269, emphasis in original) are the foundation of globally orientated subjects such as GCE where educators engage in activism (Biccum, 2015). Social movement learning (see Hall and Turay, 2006), a discipline spanning social movements and adult education, places a similar emphasis on ideas, praxis and understanding how engagement with global issues in social movements creates knowledge and educational possibilities (Holford, 1995; Foley, 1999). Despite being underpinned by similar overarching aims of understanding how people engage with the world, approaching GCE as a space of activism (Biccum, 2015) and understanding how social movements can inform GCE curriculum and practice is a comparatively recent endeavour, but one that is, in the current context, particularly urgent. In this article, GCE is employed to refer to content and practices in an educational setting that engage with issues of social injustices and inequalities from a global perspective, thereby deepening learners' understanding of 'how the world works - or does not work' (Davies, 2006: 23).

I draw on cognitive approaches to social movements (see Eyerman and Jamison, 1991) that examine collective spaces and experiences through which individuals gain transformative knowledge for social change (Finger, 1989). Accounts of transnational activism also frame social movements as ideas and global networks of people who share solidarities (Castells, 2012; Bermudez, 2011), and they establish diaspora and migrants as political agents who mobilize in spaces within, beyond and across national borders to create political change (Sheffer, 2003; Sökefeld, 2006; Lyons and Mandaville, 2010; Adamson, 2012). However, accounts are dominated by analyses of activism in liberal sociopolitical contexts, which fail to recognize that understandings and practices of resistance are culturally and contextually situated. For instance, under the constraints of authoritarianism, the art of presence of everyday, ordinary actions 
and non-movements enable imaginations of sociopolitical change (Bayat, 2010). As a cognitive space of resistance, activism is not restricted to protests, formal groups or organizations but exposes 'mutual recognition' (Bayat, 2010: 22) as important to understanding learning in social movements and GCE in a context of multiculturalism.

The fields of GCE and social movement learning share a conceptual space in which activist-educators encourage others to engage in practices of dialogue and explore complex ideas about the world (Foley, 1999; Hall and Turay, 2006; Davies, 2006; Andreotti, 2010; Bickmore and Parker, 2014; Bourn, 2014). Although learners come to their understandings of the global context from very different positions and starting points (Bourn, 2014) and activists bring their own experiences to a movement, the 'coercive process' of knowledge production 'reproduce[s] the same ways of knowing, thinking and relating' and ultimately leads to the quest for consensus (Andreotti, 2009: 9). By assuming that learners and activists have universal understandings of what is right or wrong, both spaces arguably deviate from the Freirean notion of critical consciousness (Freire, 1996) that should encourage questioning and interrogation of ideas, including how knowledge and education are constructed to retain power 'over'. Having access to different sides of a debate is critical because 'conflicting ideas enable us to become critically aware' (McCloskey, 2014: 7), suggesting that, without engaging with alternative viewpoints, understanding of and commitment to globally orientated perspectives might weaken. Being challenged, therefore, is not just a question of arriving at a new position: challenge is necessary for understanding why we think the way we do and developing commitment to critically engaged praxis (Freire, 1996).

\section{Learning through agonistic challenge}

Reframing GCE as a social movement reimagines the contribution of GCE to engaging learners in debate that exposes the political (Mouffe, 2005) and opens eyes to 'conflicting ideas and propositions', an integral process for becoming critically aware, conscious and ready to intervene in the world (McCloskey, 2014: 7). Therefore, exposure to difference is a key demand if activists and global learners are to engage in critical reflection and action.

Critics of the post-political turn towards consensus-based politics highlight the problematic removal of conflict, arguing that opposition is necessary for there to be real choice (see Rancière, 1999; Mouffe, 2005; Wilson and Swyngedouw, 2014). The denial of difference has reduced political debate to moralistic choices between right and wrong, ultimately seeking to destroy the 'enemy' rather than engage with them as 'legitimate' opponents (Mouffe, 2005: 52). When read pedagogically, Mouffe's position has significant implications for thinking about the possibilities for learning in times of division and conflict. Two intersecting ideas are particularly important to this reading. First, rejecting consensus in favour of a vigorous, assertive and interruptive democracy recognizes the productive force and pedagogical possibilities within the many complexities of conflict (Davies, 2008, 2014). Second, agonistic respect for difference creates a shared 'symbolic space within which the conflict takes place' (Mouffe, 2005: 20). This space - in this context, a classroom, protest or revolutionary moment - makes possible epistemological pluralism through dialogue that encourages people to 'deand re-construct their conceptualizations' (Andreotti, 2009: 12). Such insights would develop understandings of the processes through which relationships transform (or fail to) from an adversarial friend/enemy dichotomy to agonistic respect for difference.

This article is situated in Davies's (2004: 216) broad conceptualization of conflict that reinforces affective dimensions of struggle, the incompatibility of conflict with 
consensus and dialogue as the emergence of 'new and previously hidden meanings and understandings'. Intersections of affect and dialogue are also present within Bickmore and Parker's (2014: 302) typology of conflict dialogue which establishes 'recognition of alternative perspectives ... communication of one's own perspective ... and orally voicing and responding to other's ideas' as key tenets for addressing divergent perspectives in classrooms. Theorizing agonistic possibilities for learning requires attention to how activists and learners feel about divergent views and their opponents in order to understand how and why friend/enemy relations can become agonistic. As Clover (2012: 90) argues, 'it is emotive and affective learning, and not simply the cognitive, that can best challenge today's technically rationalized industrial culture' that negates the role of passions and identity in today's politics (Mouffe, 1993).

While it is recognized that emotions are significant for understanding why people participate in a social movement (Jasper, 1998; Goodwin et al., 2001; Goodwin and Jasper, 2004; Gould, 2004), more work is needed on understanding the intersections of emotion and learning in the context of activism. Having been dismissed as belonging to the realm of private, domestic and feminine (see Ruitenberg, 2009), Boler (1999: 7) established emotions as 'not only informing our ethical lives and cognitive perceptions, but as a political terrain'. Emotions - as embodied and situated dimensions of the affective and cognitive human experience - invite recognition of how feeling and understanding intersect. In contexts of division and conflict, this includes paying attention to how and why ideas and perspectives, for example in relation to stereotypes based on what we think we know about the 'other' (see Hall, 1997; Bickmore and Parker, 2014), materialize, strengthen and might be challenged.

Engaging with concepts such as 'power, conflict, structure, values and choice' exposes activists to ideas that are challenging to confront (Foley, 1999: 64). Pedagogically, reflecting on previously established knowledge theoretically enables learners to experience 'encounters with doubt' that expose them to 'alternative versions of truth' (Davies, 2014: 465) and reinforces challenge, discomfort (Bateson, 1994) and disruption (Richardson, 2008) as key to conceptualizing unlearning. This requires further reflection on how activists and educators enable others to 'learn to unlearn, to see different choices and possibilities and to imagine and to think "otherwise"' (Andreotti, 2009: 10). In order to develop agonistic pedagogies, we also need to consider what might prevent agonistic ways of thinking and constrain engagement with difference and the 'educative turbulence' that enables the creation of 'alternative narratives of the self' (Davies, 2014: 464).

The theoretical ideas outlined in this section acknowledge that 'learning to unlearn and to learn from others - to question long-held beliefs and open oneself to different forms of knowledge is never easy' (Andreotti and De Souza, 2008: 6) but argues it necessary for a vigorous democracy where the 'other' is an agonistic partner in a constant process of de- and re-construction of ideas and perspectives (Andreotti, 2009). The unease associated with different perspectives is integral to a radical agonistic pedagogy of global learning and unlearning where the friend/ enemy relation is reimagined as agonistic (Mouffe, 2005) and has potential to disrupt perspectives of the 'other'. Social movements and GCE must be cognitively disruptive; it is through questioning of assumptions and encounters with other worldviews that different conceptualizations of a global citizen are possible (Richardson, 2008). The remainder of the article explores the possibilities for learning and unlearning in a case of activism before reflecting on the implications for theorizing GCE. 


\section{Egyptian context struggle/activism: Three stories of Egypt's struggle}

This article draws on doctoral research with UK-based diaspora Egyptians who participated in activism associated with the Egyptian Revolution of 25 January 2011 (Underhill, 2017). This section provides a brief and, I acknowledge, simplified introduction to the context in which activists narrate their accounts that shape possibilities for learning and unlearning (for a particularly useful summary of the social and political context, see Marfleet, 2016).

The legacy of military leader Gamal Abdel Nasser is significant to understanding differences in how Egypt's recent history is interpreted. In 1954, Nasser realized Egypt's independence from the British and began 55 years of rule by leading military generals under the Supreme Council of the Armed Forces (SCAF). Nasser's significance within the popular political imaginary (Youssef et al., 2014) is evidenced by the coining of the term Nasserism which reflects specific elements of his presidency, including the notion of the magnetic yet autocratic leader and protest against Western colonialism and imperialism (Podeh and Winckler, 2004: 1-7). Following the assassination of Nasser's successor, Hosni Mubarak took office and, as a military leader, immediately implemented emergency law to extend the powers of the police, security forces and SCAF, which remained in place for 30 years.

Mubarak's regime was not without its opposition. The Muslim Brotherhood were the most organized and widespread formal political opposition (Wickham, 2013) although action from leftist movements such as Kefaya ('enough') grew alongside student and worker protests, demonstrations and walk-outs (see Abdalla, 1985; Fahmi and Sutton, 2006; Shorbagy, 2007; El-Mahdi and Marfleet, 2009; Joya, 2011; Ali, 2012; Alexander and Bassiouny, 2014; De Smet, 2015; Marfleet, 2016). Growing dissatisfaction with deteriorating economic, social and political conditions resulted in the 25 January Egyptian Revolution in 2011. Despite the success of the demonstrations that removed Mubarak on 11 February, the oppressive political space cultivated under Nasser and secured under Mubarak had entrenched divisions, ensuring different political groups that all sought an end to military rule were unable or unwilling to work together (Masoud, 2011; Altan-Olcay and Icduygu, 2012; El Naggar, 2012; Wickham, 2013). The lack of coordination between opposition groups and movements ultimately benefited the Muslim Brotherhood (MB) and in 2012, MB leader, Mohammed Morsi, was elected as president.

Morsi's election is significant because of the events that followed. Frustrations at his 'Islamization' of social, economic and legal policies and the worsening living conditions (Salamey, 2015; Achcar, 2016; Marfleet, 2016) prompted Tamarod (rebel) to petition for early elections and organized mass protests for 30 June 2013 (Elyachar, 2014). Morsi was detained by SCAF and given 48 hours to resign, prompting widespread civil unrest and sectarian violence throughout July and August 2013, which culminated in the massacre of over 1,000 Morsi supporters at sit-in demonstrations in Raba'a and al-Nahda squares in what has been referred to as 'the biggest state-sponsored killing in Egypt's history' (Marfleet, 2016: 166). As the defence minister at the time, Abdel Fattah el-Sisi assumed the position as president and was later confirmed through elections in 2014, reviving debates over whether Egypt had experienced a popular coup d'état or made way for a counter-revolution (see Giordani, 2013; Mada Masr, 2013, Underhill, 2016b). The research was conducted in the aftermath of Raba'a and in the lead up to the 2014 presidential elections when attitudes towards Morsi, el-Sisi and the revolution more broadly became sharper and more divisive, resulting in three core 
positions: anti-coup, nationalist and revolutionary. These labels are discussed as part of the methodology in the following section.

\section{Methodology and data collection}

The article draws on doctoral research conducted during 2014 that sought to understand what, how and with what effect activists learn as they participate in struggles for social change (Underhill, 2017). The diasporic experience is complex. For some, identification with the 'imagined community' (Anderson, 2006) is critical to their ontological and epistemological ways of being in relation to both host and homeland, and the contention of feeling at 'home' (Sheffer, 2003). As people who are connected to more than one place, diaspora perspectives can offer valuable insights into notions of the global as informed by multiple identities and multiple contexts. I define diaspora as conscious and engaged in their identification with Egypt (see Sökefeld, 2006; Lyons and Mandaville, 2010) so participants include migrant and British-born Egyptians equally. It is important to note that the research focuses on activists, so findings are not representative of all Egyptians living in the UK. Pseudonyms have been used throughout.

Semi-structured interviews with 28 UK-based activists were completed in 2014. It was important for participants to explore their experiences in their own words so, although conducted in English, I could explore Arabic phrases with participants having spent time in Egypt in the 2000s. As a form of ethnographic research I was also a partially participating observer (Bryman, 2012) at events organized by different groups. Although Egyptians live disparately across the UK (Karmi, 1997; Fawzy, 2012), observations took place in London outside the Egyptian embassy, at Trafalgar Square, Downing Street and Marble Arch. Initially, I learned about the events online but as the research progressed, activists would invite me directly through text messaging. Regular attendance at the embassy meant that the diplomatic police stationed outside would update me on activity on any days I had missed, an additional form of triangulation that had not been considered in the project planning. Interview participants were selected purposively to reflect a balance of gender and age.

The analysis involves forms of interpretive enquiry that draw out cultural and contextual aspects of the accounts (Riessman, 1993) and recognize that 'narratives and counter-narratives form the frameworks through which we conceive of and pursue politics' (Alexander-Floyd, 2013: 471). Being in dialogue with the data and constructing learning narratives (Foley, 1999) through iterative engagement with activists' words was critical in exposing how division shaped learning, a finding that necessitated the presentation of activists' words alongside a dominant group identification: anti-coup, nationalist or revolutionary. Despite being contentious to assign labels and there being many more ways in which allegiances could be signified (see Gerhart Center, 2013; Dunne, 2015), the three positions are necessary for delineating and analysing how division shaped learning during this period, and for contextualizing the participants' words ontologically.

References to anti-coup activism highlight pro-Morsi, MB or Islamist attitudes, though it should not be assumed that all anti-coup activists aim for the Islamization of politics. Sisi supporters revealed a 'militaristic, populist and anti-foreign' Nasserist brand of nationalism (Dunne, 2015: 1), though it should also be noted that some had been supportive of the 25 January sit-ins against Mubarak. Finally, I use the term revolutionary to include leftists, secular youth, workers and human rights defenders who actively sought to counter Islamist and nationalist forces, and who called for 
'bread, freedom and social justice' (Alexander and Bassiouny, 2014). The remainder of the article outlines the findings from the research, paying attention to activists' words to explore agonistic possibilities for learning and unlearning.

\section{Conflict and emotion in unlearning}

The complex dynamics of the Egyptian struggle produced a context that was intellectually and emotionally unsettling for activists, which was critical for prompting learning and unlearning. For many within the revolutionary and anti-coup movements in particular, activism generated new questions. Learning in this context was often a deeply personal process, acted upon individually and through stepping-back from the lived experience. In the period that followed the initial 18 days of protests in 2011, revolutionaries who stepped back from daily activism revealed that they gained the space necessary to reflect on their experiences and consider alternative perspectives, as Faoud, a revolutionary and participant interviewed, illustrates:

After the Revolution ... it was as if you [were] looking at a mystical forest. You don't know what is inside [laughs]. You know that it is corrupt, you know it is wrong ... but you don't know what's happening ... [I spent] almost every day throughout the three years reading new articles that made [me] think new things.

Faoud reveals a temporal dimension to critically conscious learning and unlearning: 'personal experience is its necessary point of departure, but for critical consciousness to emerge people must gain theoretical distance from their subjective experience' (Foley, 1999: 50). Reflecting on experiences through theoretical concepts and the passage of time is deeply personal and often intellectually and emotionally challenging. When revolutionary and anti-coup activists recounted their struggle to understand the violence that enabled the military to return with such force, they often referred to their own reading. Sana (revolutionary) read to question the ideologies underpinning the revolutionary movement, acknowledging, 'first you start reading some articles, then you start agreeing with some, and then disagreeing'. Engaging with doubt by intentionally seeking new information was key for many activists to question previously held truths and engage critically with new perspectives gained through activism.

Shifts in perspectives occur through confusion and unease. The discomfort associated with learning (Bateson, 1994) can provoke new questions and engagement with new or different ideas, the foundations for unlearning. For some revolutionary and anti-coup activists, historicized truths about the state could only be unlearned through the experiences of violence during the struggle and the subsequent connections they made to the social contract. State violence towards protestors began during the 18-day sit-in during January and February 2011 and continued throughout the struggle. Some particularly violent events regularly featured within activists' accounts: The camel battle in Tahrir Square in February 2011; violence at the Ministry of Defence at Abbasiyya by 'plain-clothed' 'thugs' in July 2011 (Youssef et al., 2014); the massacres at Maspero (Egypt's state television centre in Cairo) in October and on Mohamed Mahmoud Street off Tahrir Square in November (Al-Jaberi, 2012); what came to be known as incident of 'the girl in the blue bra' in Tahrir Square in December of the same year (see Hafez, 2014; Pratt, 2015); riots that resulted in the deaths of over 70 hardcore and predominantly working class football fans known as the Ultras at Port Said in February 2012 (see Marfleet, 2016: 128). Being present at or becoming conscious of the many incidents of police brutality challenged Eman's perspective of the police - and, 
subsequently, the state - as protectors. Eman, a revolutionary, embodied this new understanding by choosing not to live in fear of the security services and making state apparatus the direct target of her actions. Having unlearned attachment to the military by critically engaging with oppositional discourses (Foley, 1999), Eman's unconscious and conscious learning and unlearning worked together, resulting in the ultimate rejection of the truth that the army would protect the people. For these activists, the experience of conflict was key to unlearning the nationalist slogan of the army and the people as one hand.

In contrast, nationalist perspectives were rooted within a 'stability and security' justification for military rule, which dominated Egypt's state-run media and was part of the Nasserist national consciousness. The willingness of nationalists to rationalize violence in the name of the nation state suggests some perspectives are more challenging to unlearn than others:

I am unhappy about police abuse, it's not nice, especially if it is one of my family or I am exposed to any of these abuses. It is disastrous, but you have to be realistic about how to sort it out ... my personal view there are two important issues. First, to establish the security of the state, holding it together otherwise we could have ended like Syria or Libya or Yemen so in a sense we are lucky that we have a strong army. And also rebuilding the police force ... to re-establish its control on the streets so people feel secure. (Sameh, nationalist, participant interview)

Sameh's views are indicative of many of Nasser's generation who take a self-identified 'pragmatic' view of the military predicated on notions of the 'other' and securitization. Another nationalist, Hany, was more vehement in his depiction of the Muslim Brotherhood as Egypt's key threat: 'What they want you to do is to hate the police and hate the army and they just want to destroy Egypt. This is why they are killing people now.' Hany reveals how essentializing discourses of the 'other' promote an adversarial version of the we/they relation based on 'nationalist antagonisms' (Mouffe, 2005: 28) and an affective dimension that forecloses exposure to difference and, subsequently to alternative perspectives and agonistic pedagogies.

\section{Constraints and receptivity}

Among activists who were or had been engaged in movements or events associated with the continuing Egyptian revolution, attitudes towards, and perceptions of, those with different allegiances have largely been shaped by (often emotionally laden) interpretations of history and essentializing of narratives of the 'other'. These narratives result in biases and stereotypes that shape the expectations we have of others, making us more or less receptive towards learning from or with them. For example, anti-coup activists admitted checking a person's position on the coup before deciding whether to engage in a conversation or not (see Underhill, 2016b), while Khaled, a revolutionary, admitted 'the discussions with the Islamists ... were not serious but more a way of killing time' during the long days of sit-ins during the Egyptian Revolution of 25 January 2011.

Acknowledging that 'personal bias can be blinding', Walid, a revolutionary, reflected on the divisions within his own family and the frustration that he and his brother (both students) felt at the widespread attachment to Nasser and, by extension, the military. Situating Nasser's policies within Egypt's history of breaking with colonialism emphasizes pride in national identity and belonging to Egypt's 'imagined community' (Anderson, 2006). Through Egyptianization and the strong-man demeanour, 'the King, 
Nasser' (Walid, revolutionary) 'enjoyed a sacrosanct place in the national imagination' (Youssef et al., 2014: 872) that went beyond the notion of a leader, as Nour, a revolutionary and participant interviewed, explains:

It's not just Nasser's politics, it is Nasser's culture. It's the music, the arts, the literature. All this was also about that man and his Revolution and postcolonialism ... that was a glory period and that was emancipation from the British, that was winning stuff: winning '56, winning '74 ... when they [elders] hear 'the military', it's not about Mubarak etc. They just hear 'Our Saviour' and the people that liberated us from the British and are a source of pride. They just don't understand that any institution is represented by its people.

Nasser's reification as the leader that brought about national pride and independence extended to the military more broadly and enabled the heavily securitized state apparatus (Kandil, 2012; Marfleet, 2016) to establish the 'other' as dangerous to freedom and security, with two key targets: Islamists and foreign sponsored traitors (including Egyptians who had been educated or lived in the global North) who challenged Egypt's autonomy. The essentializing of Egypt's history ensured the army's position as the necessary protectors of freedom from imperialism and security from terrorism and, in the continuing struggle, were critical to representing revolutionaries as 'naïve' (Ashraf, nationalist) and anti-coup activists as associated with a 'terrorist group' (Hany, nationalist). It is in this context that in 2014, with a generation that 'for all of his life he has been raised not to question the military, not to think' (Adel, anti-coup), Nasserists like Hany easily 'switched to Sisi' (Khaled, revolutionary) and continue to support the military autocracy, even amid deteriorating social, political and economic conditions (Hamzawy, 2017).

Historical perceptions of conflict shape learning (Davies, 2004). While nationalist perspectives derive their pull from an historicized, imagined Egypt and enigmatic leader, learning within the anti-coup movement has been shaped by the much more recent event that many lived and experienced: the coup in July 2013 and the subsequent massacre of Morsi supporters at Raba'a. The violence prompted intense reactions from all sides and suggests that the complexity of the struggle was subsumed into narrower interpretations of a person's group identification. For example, many anti-coup activists blamed revolutionaries who had joined the protests organized by Tamarod on 30 June 2013. One activist reflected that her family's attachment to the military meant they were willing to support the killing of Morsi supporters:

I know my cousins wanted Raba'a. They wanted the massacre. I can't talk to them anymore ... I showed them the pictures and they still felt they would support the military and this was the time I decided I would not talk to them. I would tell them the blood of this person is on your hands. (Salma, anti-coup, participant interview)

Salma's reflection illustrated that the emotions associated with struggle, while useful for instigating and sustaining movement participation (Jasper, 1998; Goodwin et al., 2001), the strength of feeling was also a factor in constraining the possibilities for people from different sides to learn with and from each other's perspectives. Similarly, Tayeb (anti-coup) also avoided discussions with people beyond the anti-coup position, admitting that 'if somebody says they were wrong and they deserved to die or Sisi is a national hero and he is going to save the country, then there is no scope for discussion. And that's it for me.' These honest accounts of a significant moment in Egypt's 
contemporary struggle reveal the implications of narrow interpretations of opponents that essentialize and homogenize. In this form of conflict, possibilities for agonistic imaginaries are limited. To illustrate further, activists from three different perspectives of Egypt's struggle were divided after Raba'a, as Mohammed (anti-coup) reflected: 'People won't work with the Islamists. They see Tamarod [movement credited with organizing the 2013 protests] is behind bars, April 6 behind bars, leftists like Alaa Abdel Fattah [prominent activist and blogger] behind bars ... but they still won't want to work with us. They want to work alone.' Despite anti-coup and revolutionary activists sharing in the hope of seeing the end of military rule, the adversarial relationships had been intensified by the massacre at Raba'a and Morsi's detention. A common perspective from anti-coup activists was to suggest that being for or against the military was, by extension, equal to being for or against the massacre, a position that arguably constrains the opportunities to engage with more alternative perspectives:

The real issue here is not the political positions, either. Not about being MB backers or liberal backers or 6th of April backers or military backers. It is nothing to do with that. The splits are now because of the blood that has been spilt ... you can't be indifferent on a matter like this, you can't have that freedom because it is about death, death of people, it's about blood. You have to have an opinion when it comes to blood being spilled. (Adel, anti-coup, participant interview)

Approaches to conflict resolution show it is necessary 'not to establish some correct "truth", but to surface different interpretations of significant and critical "events" - as well as surfacing the complexity of all the people who might have a bearing' (Davies, 2004: 187). However, as Dina (revolutionary) reflected, this is 'about the ability of everyone to be self-critical and learn over time ... [in Egypt] you see people taking extreme sides because they are very stubborn and stick to the [view that] the world is one thing.' Engaging with complexity is demanding but, as this case shows, a necessary aspect of agonistic approaches to education and learning.

\section{Conclusions: Agonistic possibilities for global unlearning}

The case study outlined above illustrates the complexities associated with learning and unlearning in conflict and division, drawing on Mouffe's (2005) theory of agonistic pluralism to explore new connections between social movement learning and GCE. While both spaces involve engaging with ideas of the way the world could be, 'in the current neoliberal context of globalization, educating for global citizenship is much more, and I would add, essentially so, about dissensus than consensus; much more about disrupting existing narratives than embracing a political consciousness on a global scale' (Richardson, 2008: 130). To this end, this article explores the possibilities offered by agonism, a conceptualization of relationships that does not deny conflict but recognizes it is inevitable and necessary within democracy (Mouffe, 2005).

This article has outlined a unique example of learning in social movements with insights from different 'sides' of a struggle that expose how relationships and lived experiences shape possibilities for learning and unlearning. Having established activists gain new perspectives through theorizing their experiences and observations, further research is needed to understand how activists' processes of theorizing might inform pedagogies for learning and unlearning within GCE. Similarly, it is evident that unlearning requires engaging with oppositional discourses in ways that can be uncomfortable and challenging, a finding that revealed affect and emotion 
as critical conceptual tools for understanding GCE and social movement learning. While emotions are present in both fields, more work is needed to understand the connections between emotion, conflict, receptivity and constraints in the context of agonism.

This research is particularly relevant for the contemporary moment where the notions of 'us' and 'them' have been made more complex within the global context of migration (Davies, 2006) and for considering how to develop pedagogy and subject content that supports students for the current conflictual context (Bickmore, 2005). This context demands approaches within GCE that are disruptive and 'embrac[e] political consciousness on a global scale' (Richardson, 2008: 130), enabling young people to learn through the 'dissonance' and 'disequilibrium of collaborative pluralist contexts' that disrupt how individuals perceive the world (Beaumont, 2011: 219). However, it is important to remain critical of a depoliticized approach to encounters that suggest opportunities to engage with different perspectives will change students' perceptions of the 'other' (Richardson, 2008). This article has established that encounters cannot be assumed to enable a shift in understanding or perspective and revealed receptivity to be a significant factor in shaping opportunities to learning and unlearning that needs further research and theorization.

Globalization has generated multiple possibilities for 'real and conceptual' spaces of transnational mobilization where movement actors can learn from each other (Byrd, 2005: 152). While 'a multicultural context can open significant critical possibilities for making sense of today's complexities and for imagining new ways of relating as citizens' (Pashby, 2015: 361), the specification of unlearning outlined in this article makes explicit the historical and affective constraints that can prevent agonistic relationships of learning. The notions of constraint and receptivity presented in this article contribute to and build on the understanding that 'connections between sociohistorical processes and encounters ... have shaped our contexts and cultures and the construction of our knowledges and identities' (Andreotti, 2010: 246). Agonistic possibilities depend on understanding how these connections impact our perceptions of and engagement with the 'other'. However, it is also through engaging with our own ontological and epistemological positions that the possibilities for deconstructing the us/them relation emerges, and with them the construction of new pedagogical imaginaries. It follows, then, that if activists and educators are to 'transform antagonism into agonism' (Mouffe, 2005: 20), there is an urgent need to engage more deeply with processes of unlearning and the barriers and constraints that shape new imaginations and ways of seeing and knowing. Following Mouffe, Mihai (2014) argued that a lack of agonism would result in an increase in far-Right tendencies. The realities of the contemporary moment substantiate this concern and further remind us of the necessity and global significance of theory and practice that can seek to understand how ideas of the self and the 'other' are imagined and reimagined, learned and unlearned.

\section{Notes on the contributor}

Helen Underhill is Lecturer in Education at Manchester Metropolitan University, UK, where she contributes to postgraduate taught and research programmes across the faculty, and to research groups within the Education and Social Research Institute. Her research builds on a PhD on social movement learning, and explores various theoretical and methodological intersections of education and global development. 


\section{References}

Abdalla, A. (1985) The Student Movement and National Politics in Egypt, 1923-1973. London: Al Saqi Books.

Achcar, G. (2016) Morbid Symptoms: Relapse in the Arab uprising. Stanford: Stanford University Press.

Adamson, F.B. (2012) 'Constructing the diaspora: Diaspora identity politics and transnational social movements'. In Lyons, T. and Mandaville, P. (eds) Politics from Afar: Transnational diasporas and networks. London: Hurst and Company, 25-42.

Alexander, A. and Bassiouny, M. (2014) Bread, Freedom, Social Justice: Workers and the Egyptian Revolution. London: Zed Books.

Alexander-Floyd, N.G. (2013) '(Inter)disciplinary trouble: Intersectionality, narrative analysis, and the making of a new political science'. Politics and Gender, 9 (4), 470-4.

Ali, K. (2012) 'Precursors of the Egyptian Revolution'. IDS Bulletin, 43 (1), 16-25.

Al-Jaberi, A. (2012) 'Out of sight, but not out of mind: Mohamed Mahmoud remembered'. Egypt Independent, 18 November. Online. https://tinyurl.com/y5mudzol (accessed 8 September 2019).

Altan-Olcay, O. and Icduygu, A. (2012) 'Mapping civil society in the Middle East: The cases of Egypt, Lebanon and Turkey'. British Journal of Middle Eastern Studies, 39 (2), 157-79.

Anderson, B. (2006) Imagined Communities: Reflections on the origin and spread of nationalism. Rev. ed. London: Verso.

Andreotti, V. (2009) 'Global education in the "21st century": Two different perspectives on the "post-" of postmodernism'. International Journal of Development Education and Global Learning, 2 (2), 5-22.

Andreotti, V. (2010) 'Postcolonial and post-critical "global citizenship education"'. In Elliott, G., Fourali, C. and Issler, S. (eds) Education and Social Change: Connecting local and global perspectives. London: Continuum, 238-50.

Andreotti, V. and De Souza, L.M.T.M. (2008) Learning to Read the World through Other Eyes. Derby: Global Education.

Bateson, M.C. (1994) Peripheral Visions: Learning along the way. New York: HarperCollins.

Bayat, A. (2010) Life as Politics: How ordinary people change the Middle East. Amsterdam: Amsterdam University Press.

Beaumont, E. (2011) 'Promoting political agency, addressing political inequality: A multilevel model of internal political efficacy'. Journal of Politics, 73 (1), $216-31$.

Bermudez, A. (2011) 'The "diaspora politics" of Colombian migrants in the UK and Spain'. International Migration, 49 (3), 125-43.

Biccum, A.R. (2015) 'The politics of education for globalisation: Managed activism in a time of crisis'. Australian Journal of International Affairs, 69 (3), 321-38.

Biccum, A.R. (2018) 'Editorial: Global citizenship education and the politics of conceptualization'. International Journal of Development Education and Global Learning, 10 (2), 119-24.

Bickmore, K. (2005) 'Teacher development for conflict participation: Facilitating learning for "difficult citizenship" education'. International Journal of Citizenship and Teacher Education, 1 (2), 2-16.

Bickmore, K. and Parker, C. (2014) 'Constructive conflict talk in classrooms: Divergent approaches to addressing divergent perspectives'. Theory and Research in Social Education, 42 (3), 291-335.

Boler, M. (1999) Feeling Power: Emotions and Education. New York: Routledge.

Bourn, D. (2014) 'Typologies of development education: From learning about development to critical global pedagogy'. In McCloskey, S. (ed.) Development Education in Policy and Practice. Basingstoke: Palgrave Macmillan, 47-64.

Bryman, A. (2012) Social Research Methods. 4th ed. Oxford: Oxford University Press.

Byrd, S.C. (2005) 'The Porto Alegre Consensus: Theorizing the Forum Movement'. Globalizations, $2(1), 151-63$.

Castells, M. (2012) Networks of Outrage and Hope: Social movements in the internet age. Cambridge: Polity Press.

Clover, D.E. (2012) 'Aesthetics, society and social movement learning'. In Hall, B., Clover, D., Crowther, J. and Scandrett, E. (eds) Learning and Education For a Better World: The role of social movements. Rotterdam: Sense Publishers, 87-100.

Davies, L. (2004) Education and Conflict: Complexity and chaos. London: RoutledgeFalmer.

Davies, L. (2006) 'Global citizenship: Abstraction or framework for action?'. Educational Review, 58 (1), 5-25. 
Davies, L. (2008) 'Interruptive democracy in education'. In Zajda, J., Davies, L. and Majhanovich, E. (eds) Comparative and Global Pedagogies: Equity, access and democracy in education. Dordrecht: Springer, 15-31.

Davies, L. (2014) 'Interrupting extremism by creating educative turbulence'. Curriculum Inquiry, 44 (4), 450-68.

De Smet, B. (2015) A Dialectical Pedagogy of Revolt: Gramsci, Vygotsky, and the Egyptian Revolution. Leiden: Brill.

Dunne, M. (2015) 'Egypt's nationalists dominate in a politics-free zone'. Carnegie Endowment for International Peace, 15 April. Online. https://tinyurl.com/yxn98syw (accessed 8 September 2019).

El-Mahdi, R. and Marfleet, P. (eds) (2009) Egypt: The moment of change. Cairo: American University in Cairo Press.

El Naggar, M.H. (2012) 'Human rights organisations and the Egyptian Revolution'. IDS Bulletin, 43 (1), 78-86.

Elyachar, J. (2014) 'Upending infrastructure: Tamarod, resistance, and agency after the January 25th Revolution in Egypt'. History and Anthropology, 25 (4), 452-71.

Eyerman, R. and Jamison, A. (1991) Social Movements: A cognitive approach. Cambridge: Polity Press.

Fahmi, W.S. and Sutton, K. (2006) 'Cairo's Zabaleen garbage recyclers: Multi-nationals' takeover and state relocation plans'. Habitat International, 30 (4), 809-37.

Fawzy, S. (2012) 'Egyptian migrants in the UK: A reading after the 25th of January Revolution'. In A Study on the Dynamics of Arab Expatriate Communities: Promoting positive contributions to socioeconomic development and political transitions in their homelands. Cairo: International Organization for Migration, 41-54.

Finger, M. (1989) 'New social movements and their implications for adult education'. Adult Education Quarterly, 40 (1), 15-22.

Foley, G. (1999) Learning in Social Action: A contribution to understanding informal education. London: Zed Books.

Freire, P. (1996) Pedagogy of the Oppressed. Trans. Ramos, M.B. London: Penguin Books.

Gerhart Center (British Council and John D. Gerhart Center for Philanthropy and Civic Engagement) (2013) The Revolutionary Promise: Youth perceptions in Egypt, Libya and Tunisia: Summary. Cairo: British Council. Online. https://www.issuelab.org/resources/20465/20465.pdf (accessed 4 July 2019).

Giordani, A. (2013) 'Keywords: Revolution/Coup d'état'. Jadaliyya, 1 August. Online. www.jadaliyya. com/Details/29218 (accessed 6 July 2019).

Goodwin, J. and Jasper, J.M. (2004) Rethinking Social Movements: Structure, meaning, and emotion. Lanham, MD: Rowman and Littlefield.

Goodwin, J., Jasper, J.M. and Polletta, F. (2001) 'Introduction: Why emotions matter'. In Goodwin, J., Jasper, J.M. and Polletta, F. (eds) Passionate Politics: Emotions and social movements. Chicago: University of Chicago Press, 1-24.

Gould, D.B. (2004) 'Passionate political processes: Bringing emotions back into the study of social movements'. In Goodwin, J. and Jasper, J.M. (eds) Rethinking Social Movements: Structure, meaning, and emotion. Lanham: Rowman \& Littlefield Publishers, 155-76.

Hafez, S. (2014) 'Bodies that protest: The girl in the blue bra, sexuality, and state violence in revolutionary Egypt'. Signs: Journal of Women in Culture and Society, 40 (1), 20-8.

Hall, B. and Turay, T. (2006) A Review of the State of the Field of Adult Learning: Social movement learning. Ottawa: Canadian Council on Learning.

Hall, S. (ed.) (1997) Representation: Cultural representations and signifying practices. London: SAGE Publications.

Hamzawy, A. (2017) 'Legislating authoritarianism: Egypt's new era of repression'. Carnegie Endowment for International Peace, 16 March. Online. https://tinyurl.com/y4soq2hw (accessed 8 September 2019).

Heater, D. (2004) Citizenship: The civic ideal in world history, politics and education. 3rd ed. Manchester: Manchester University Press.

Holford, J. (1995) 'Why social movements matter: Adult education theory, cognitive praxis, and the creation of knowledge'. Adult Education Quarterly, 45 (2), 95-111.

Jasper, J.M. (1998) 'The emotions of protest: Affective and reactive emotions in and around social movements'. Sociological Forum, 13 (3), 397-424.

Joya, A. (2011) 'The Egyptian Revolution: Crisis of neoliberalism and the potential for democratic politics'. Review of African Political Economy, 38 (129), 367-86.

Kandil, H. (2012) Soldiers, Spies, and Statesmen: Egypt's road to revolt. London: Verso. 
Karmi, G. (1997) The Egyptians of Britain: A migrant community in transition (CMEIS Occasional Paper 57). Durham: Centre for Middle Eastern and Islamic Studies.

Lyons, T. and Mandaville, P. (2010) 'Think locally, act globally: Toward a transnational comparative politics'. International Political Sociology, 4 (2), 124-41.

Mada Masr (2013) 'Excuse me sir, is it a coup?'. Jadaliyya, 5 July. Online. https://tinyurl.com/yy2jvzbj (accessed 8 September 2019).

Marfleet, P. (2016) Egypt: Contested revolution. London: Pluto Press.

Masoud, T. (2011) 'Liberty, democracy, and discord in Egypt'. Washington Quarterly, 34 (4), 117-29.

McCloskey, S. (ed.) (2014) Development Education in Policy and Practice. Basingstoke: Palgrave Macmillan.

Mihai, M. (2014) 'Theorizing agonistic emotions'. Parallax, 20 (2), 31-48.

Mouffe, C. (1993) The Return of the Political. London: Verso.

Mouffe, C. (2005) On the Political. London: Routledge.

Pashby, K. (2015) 'Conflations, possibilities, and foreclosures: Global citizenship education in a multicultural context'. Curriculum Inquiry, 45 (4), 345-66.

Podeh, E. and Winckler, O. (eds) (2004) Rethinking Nasserism: Revolution and historical memory in modern Egypt. Gainesville: University Press of Florida.

Pogge, T. (2010) Politics as Usual: What lies behind the pro-poor rhetoric. Cambridge: Polity Press.

Pratt, N. (2015) 'After the 25 January Revolution: Democracy or authoritarianism in Egypt?'. In AbouEl-Fadl, R. (ed.) Revolutionary Egypt: Connecting domestic and international struggles. London: Routledge, 43-63.

Rancière, J. (1999) Disagreement: Politics and philosophy. Trans. Rose, J. Minneapolis: University of Minnesota Press.

Richardson, G. (2008) 'Within the liminal space: Re-positioning global citizenship education as politics of encounter, disruption and transcendence'. In Abdi, A.A. and Richardson, G. (eds) Decolonizing Democratic Education: Trans-disciplinary dialogues. Rotterdam: Sense Publishers, 127-38.

Riessman, C.K. (1993) Narrative Analysis. Newbury Park, CA: SAGE Publications.

Ruitenberg, C.W. (2009) 'Educating political adversaries: Chantal Mouffe and radical democratic citizenship education'. Studies in Philosophy and Education, 28 (3), 269-81.

Salamey, I. (2015) 'Post-Arab Spring: Changes and challenges'. Third World Quarterly, $36(1), 111-29$.

Schattle, H. (2008) The Practices of Global Citizenship. Lanham, MD: Rowman and Littlefield.

Sheffer, G. (2003) Diaspora Politics: At home abroad. Cambridge: Cambridge University Press.

Shorbagy, M. (2007) 'The Egyptian Movement for Change - Kefaya: Redefining politics in Egypt'. Public Culture, 19 (1), 175-96.

Sökefeld, M. (2006) 'Mobilizing in transnational space: A social movement approach to the formation of diaspora'. Global Networks, 6 (3), 265-84.

Spivak, G.C. (2004) 'Righting wrongs'. South Atlantic Quarterly, 103 (2-3), 523-81.

Stein, S. (2015) 'Mapping global citizenship'. Journal of College and Character, 16 (4), 242-52.

Troll, T. and Krause, J. (2016) 'The future of development education: Transformational learning for a world citizens movement'. In Skinner, A., Baillie Smith, M., Brown, E. and Troll, T. (eds) Education, Learning and the Transformation of Development. London: Routledge, 143-57.

Tryggvason, Á. (2017) 'The political as presence: On agonism in citizenship education'. Philosophical Inquiry in Education, 24 (3), 252-65.

Underhill, H. (2016a) 'Learning in revolution: Perspectives on democracy from Egypt's UK-based diaspora activists'. Contemporary Levant, 1 (1), 25-37.

Underhill, H. (2016b) 'Translation and diaspora politics: Narrating the struggle at "home" and "abroad"'. In Baker, M. (ed.) Translating Dissent: Voices from and with the Egyptian Revolution. London: Routledge, 45-59.

Underhill, H. (2017) 'Learning and Unlearning in Struggles for Social Change: Activism in the Continuing Egyptian Revolution'. Unpublished PhD thesis, University of Manchester.

VanWynsberghe, R. and Herman, A.C. (2015) 'Education for social change and pragmatist theory: Five features of educative environments designed for social change'. International Journal of Lifelong Education, 34 (3), 268-83.

Wickham, C.R. (2013) The Muslim Brotherhood: Evolution of an Islamist movement. Princeton: Princeton University Press.

Wilson, J. and Swyngedouw, E. (eds) (2014) The Post-Political and Its Discontents: Spaces of depoliticisation, spectres of radical politics. Edinburgh: Edinburgh University Press. 
Young, H. (2010) 'Naming the world: Coming to terms with complexity'. Policy and Practice: A Development Education Review, 10, 99-104.

Youssef, M., Arafa, H. and Kumar, A. (2014) 'Mediating discourse of democratic uprising in Egypt: Militarized language and the "battles" of Abbasiyya and Maspero'. International Journal of Communication, 8, 871-89.

Zembylas, M. (2018) 'Political emotions in the classroom: How affective citizenship education illuminates the debate between agonists and deliberators'. Democracy and Education, 26 (1), Article 6, 1-5. Online. https://tinyurl.com/y5h837uv (accessed 8 September 2019).

Zembylas, M. and Vrasidas, C. (2005) 'Globalization, information and communication technologies, and the prospect of a "global village": Promises of inclusion or electronic colonization?'. Journal of Curriculum Studies, 37 (1), 65-83. 